\title{
NATIONAL PHYSICAL LABORATORY RADIOCARBON MEASUREMENTS I
}

\author{
W. J. CALLOW, M. J. BAKER and D. H. PRITCHARD \\ National Physical Laboratory, Teddington, England
}

The dating equipment at the National Physical Laboratory was completed by the summer of 1960 . A series of calibration and intercomparison measurements was undertaken however, using the NBS oxalic acid reference standard, a modern wood standard (1850 oak tree) and other material before starting routine measurements toward the end of 1961. All results have been obtained using a $4.5 \mathrm{~L}$ copper proportional counter filled with $\mathrm{CO}^{2}$ at a constant density corresponding to standard conditions of $22^{\circ} \mathrm{C}$ and an absolute pressure of 150 $\mathrm{cm} \mathrm{Hg}$. The counter is shielded by 8 in. of steel, 6 in. of paraffin wax containing boric oxide, 23 Geiger counters arranged as two independent groups and finally by 1 in. of mercury.

The net count corresponding to 0.95 times the activity of the NBS oxalic acid is $\mathbf{5 5 . 6}$ counts/min and is statistically indistinguishable from that obtained using the 1850 oak. The background is 9.6 counts $/ \mathrm{min}$ with a residual barometric pressure effect of ca. 0.22 counts $/ \mathrm{min} / \mathrm{cm} \mathrm{Hg}$ for which a correction is applied to all measurements. All results are based on the NBS oxalic acid reference standard, are corrected for isotopic fractionation from measurements with a Metropolitan Vickers M.S. 3 mass spectrometer and reported with A.D. 1950 as the reference year. The quoted uncertainty $( \pm l \sigma)$ is calculated from the variances observed for the standard, unknown and background count rates, together with that of the correction applied for fractionation. A standard error of $80 \mathrm{yr}$ is also included for the de Vries effect, but no error is included for the half life which has arbitrarily been taken as $5568 \mathrm{yr}$. The apparatus automatically corrects for the dead time imposed during the cancellation of meson pulses and prints answers every 50 min of live time to provide the information necessary for the statistical analysis. Each measurement period is of 16 to 18 hr duration and results are reported for at least three such periods spaced at intervals of about a week and involving independent fillings of the counter. To allow any radon to decay, samples are not measured until three weeks have elapsed after final purification. The limit of sensitivity, based on a total counting time of $48 \mathrm{hr}$ and a $4 \sigma$ criterion, is between 40,000 and $45,000 \mathrm{yr}$.

Samples are pretreated with hydrochloric acid and sodium hydroxide, excepting shell which has $30 \%$ by weight removed by acid leaching only. For each measurement, gas purity is monitored using an external cobalt-60 source and the charge sensitivity of the special NPL non-overloading amplifier checked using a standard test pulse. Plateaux normally exceed $500 \mathrm{v}$ in length, centered on the operating point of $6000 \mathrm{v}$, and have a slope of $0.5 \% / 100 \mathrm{v}$. From time to time the efficiency of the Geiger counters is checked using a coincidence, anti-coincidence technique.

The description of each sample is based on information provided at the time of application by the person submitting the sample to the Laboratory. 
The work reported forms part of the research programme of the Laboratory and is published by permission of the Director.

\section{BRITISH ISLES}

\section{Penmaenmawr series, Caernarvonshire}

Carbonized wood from stone circles on moorland known as Cefn Coch, S of Penmaenmawr. Coll. 1959 and subm. by W. E. Griffiths.

\section{NPL-10. Stone circle 278, Penmaenmawr, A $3355 \pm 155$}

1405 в.C.

Sample A from old surface beneath stony bank of NE quadrant of circle $\left(53^{\circ} 15^{\prime} 08^{\prime \prime} \mathrm{N}\right.$ Lat, $03^{\circ} 55^{\prime} 01^{\prime \prime} \mathrm{W}$ Long), N Wales. Comment (W.E.G.) : associated with scraps of pottery perhaps representing camp-site of builders of circle.

\section{NPL-11. Stone circle 278, Penmaenmawr, B $\quad 3470 \pm 145$ \\ 1520 в.c.}

Sample B from old surface against main upright in SW quadrant of circle $\left(53^{\circ} 15^{\prime} 08^{\prime \prime} \mathrm{N}\right.$ Lat, $03^{\circ} 55^{\prime} 01^{\prime \prime} \mathrm{W}$ Long), N Wales. Comment (W.E.G.) : dates erection or at least use of circle.

\section{NPL-12. Monument 280, Penmaenmawr, C $\quad 3080 \pm 145$}

Sample C from contents of fire pit dug into old surface of circle $\left(53^{\circ} 15^{\prime}\right.$ $11^{\prime \prime} \mathrm{N}$ Lat, $03^{\circ} 54^{\prime} 57^{\prime \prime} \mathrm{W}$ Long), N Wales. Comment (W.E.G.) : dates a time during use of monument.

\section{Badentarbet Lodge series, Ross-shire}

Wood of Pinus Sylvestris from peat bog, ca. $50 \mathrm{ft}$ above sealevel, close to gate of Badentarbet Lodge, Achtilbuie, $\mathrm{N}$ of Ullapool $\left(58^{\circ} 02^{\prime} \mathrm{N}\right.$ Lat, $05^{\circ} 21^{\prime}$ W Long), Scotland. Coll. 1959 by T. G. Longstaff; subm. by H. H. Lamb, Meteorological Office, Air Ministry.

General comment (H.H.L.) : samples come from well-grown trees, believed to be part of the most recent forest growth, at an exposed part of coast where trees will now not grow (Manley, 1945; Lamb, 1959). The problem is whether this occurred during the main postglacial Climatic Optimum, 4000 to 2000 B.C. or the less favorable secondary optimum ca. A.D. 1000.

\section{NPL-13. Badentarbet Lodge, A}

$4420 \pm 102$

2470 B.c.

Part of $\log 17 \mathrm{ft}$ long, $7 \mathrm{in}$. diam at lower end, which had more than 90 growth rings, 2 to $3 \mathrm{ft}$ below present surface of peat. Considered by finder to show signs of fire.

\section{NPL-14. Badentarbet Lodge, B}

$$
\begin{aligned}
& 4220 \pm 105 \\
& 2270 \text { B.C. }
\end{aligned}
$$

Tree roots resting on bare glacial drift and stones, exposed by removal of peat during last $100 \mathrm{yr}$. The peat bed had been only 3 to $4 \mathrm{ft}$ thick and there was no sign of true humus. 


\section{NPL-17. Swarkestone, Derbyshire}

Charcoal, (oak and hawthorn), part of charred logs from base of secondary cremation pit inserted in top of primary barrow $\left(52^{\circ} 51^{\prime} 35^{\prime \prime} \mathrm{N}\right.$ Lat, $01^{\circ}$ $27^{\prime} 28^{\prime \prime}$ W Long), Derbyshire. Coll. 1956 by E. Greenfield; subm. by L. Biek, Ministry of Public Bldg. and Works. Comment (L.B.) : dates the secondary, overhanging-rim urn, burial.

\section{NPL-18. Codicote, Hertfordshire}

Charcoal fragments (oak) on pre-barrow surface $\left(51^{\circ} 51^{\prime} 06^{\prime \prime} \mathrm{N}\right.$ Lat, $00^{\circ} 14^{\prime} 51^{\prime \prime}$ W Long), Hertfordshire. Coll. 1956 by E. Greenfield; subm. by L. Biek. Comment (L.B.) : dates primary burial, below which surface was pottery of Middle Bronze Age and Neolithic features.

\section{NPL-19. Shearplace Hill, Dorset $\quad 3130 \pm 180$ \\ 1180 в.c.}

Charcoal and animal bone from settlement site $\left(50^{\circ} 47^{\prime} 07^{\prime \prime} \mathrm{N}\right.$ Lat, $02^{\circ}$ 30'39" W Long), Dorset. Coll. 1958 by Miss V. Russell; subm. by L. Biek. Comment (L.B.) : dates Deverel-Rimbury culture in Dorset, of which this is the first settlement site to be located.

\section{NPL-21. Gwithian, Cornwall}

$$
3070 \pm 103
$$

Charcoal (Sample 3) of cremation fires from four contemporary pits, small hollows in a sandy layer, on Site X (1960), Layer 5, Gwithian $\left(50^{\circ} 14^{\prime}\right.$ N Lat, $05^{\circ} 22^{\prime}$ W Long), Cornwall. Coll. 1961 by J. V. Megaw and A. C. Thomas; subm. by A. C. Thomas, Univ. of Edinburgh. Comment: sample required extensive separation from modern rootlets. (A.C.T.) : pits also contained part of cremated human skeletons and shell fragments and were immediately sealed by the first plow-soil. This layer seems to provide an exceptionally detailed example of Deverel-Rimbury culture, now regarded as starting in full ca. 1200 B.c.

\section{Minworth series, Warwickshire}

Samples from temporary excavation in First Terrace of River Tame, Minworth $\left(52^{\circ} 31^{\prime} 20^{\prime \prime} \mathrm{N}\right.$ Lat, $01^{\circ} 45^{\prime} 20^{\prime \prime} \mathrm{W}$ Long), Warwickshire. Coll. 1961 by P. J. Osborne; subm. by M. R. Kelly, Univ. of Birmingham.

\section{NPL-26. Minworth I}

$$
3290 \pm 95
$$

Roots traversing terrace sands, ca. $7 \mathrm{ft}$ down, overlain by clay through which they do not appear to penetrate.

\section{NPL-27c. Minworth IIb}

$$
\begin{gathered}
10,530 \pm 156 \\
8580 \text { в.с. }
\end{gathered}
$$

Detritus peat, ca. $8 \mathrm{ft}$ down, overlies gravel and underlies sand of Minworth I, with a root-free layer between the two. Comment (M.R.K.) : first known occurrence of peat from this terrace yielding a large fauna and flora resembling those of Severn Main and Avon No. 2, which have $\mathrm{C}^{14}$ dates of 42,000 and 39,000 yr respectively. Sample possibly contaminated with sewage. 


\section{NPL-39. Shustoke A. 2, Warkickshire}

$4830 \pm 100$

2880 в.c.

Plant detritus washed from organic sand layer $2 \mathrm{ft} 2 \mathrm{in}$. thick beneath 6 $\mathrm{ft} 8 \mathrm{in}$. of clay silts and sands at Shustoke Reservoirs $\left(52^{\circ} 31^{\prime} 12^{\prime \prime} \mathrm{N} \mathrm{Lat,} 01^{\circ}\right.$ 39' 18" W Long), Warwickshire. Coll. 1960 by M. R. Kelly; subm. by F. W. Shotton, Univ. of Birmingham. Comment (F.W.S.) : this provides a date for the beginning of alluviation in the Midlands, which on pollen analytical evidence appears to be ca. 5000 B.P.

\section{Haua Fteah series, Libya}

NORTH AFRICA

Wood charcoal from hearths in well-stratified deposits in the Haua Fteah cave, near Cyrene $\left(33^{\circ} 31^{\prime} \mathrm{N}\right.$ Lat, $22^{\circ} 00^{\prime} \mathrm{E}$ Long), Cyrenaica, Libya (McBurney et al., 1953; McBurney, 1961, 1962). Coll. 1955 and subm. by C. B. McBurney, Univ. of Cambridge.

NPL-40. Haua Fteah, 3

$5800 \pm 108$

Sample HFT 1955/3 from Layer VI at depth of 5 to $6 \mathrm{ft}$.

NPL-41. Haua Fteah, 4

3850 в.с.

Sample HFT 1955/4 from Layer VI.

NPL-42. Haua Fteah, 9

$4860 \pm 97$

2910 в.c.

Sample HFT 1955/9 from Layer VIII at depth of 6 to $7 \mathrm{ft}$. Comment: cf. W-98 (USGS I).

\section{NPL-43. Haua Fteah, 17}

$12,750 \pm 173$

Sample HFT 1955/17 from Layer XV and XIV.

$\begin{array}{lr}\text { NPL-44. Haua Fteah, } 83 & \mathbf{1 2 , 5 8 0} \pm \mathbf{1 7 2} \\ \text { Sample HFT 1955/83 from Layer XIV ca. } 11 \mathrm{ft} \text { below surface. Comment: }\end{array}$

10,800 в.с. cf. W-97 (USGS I).

General comment (C.B.M.) : dates increase the precision of age/depth relationship at this site, forming part of the dating evidence for a nearly complete succession of Late Pleistocene and Early Postglacial mammalian fauna of Cyrenaica. NPL-40 and NPL-41 fix the age of the Later Neolithic phase in this territory and demonstrate that this phase was the product of the Ancient Libyan people known from ancient Egyptian historical records. NPL-42 establishes the date of the earliest Neolithic and the first appearance in the area of domestic animals. NPL-43 and NPL-44 confirm the position of another cultural interface, namely, the first appearance on the S Mediterranean shoreline of European type Upper Paleolithic.

\section{The Tombs series, Queensland}

\section{AUSTRALIA}

Wood charcoal lumps from rock shelter at 'The Tombs', Mt. Moffatt Sta. 
(25 $06^{\prime}$ S Lat, $147^{\circ}$ 51' E Long), Central Queensland. Coll. 1960 and subm. by D. J. Mulvaney, Univ. of Melbourne.
NPL-30. The Tombs, 1
$3400 \pm 97$

Sample 1 from $2 \mathrm{ft}$ below surface. Comment (D.J.M.) : associated with geometric microlith artifacts.

\section{NPL-31. The Tombs, 2}

$3600 \pm 93$

1650 B.c.
Sample 2 from $3 \mathrm{ft} 6$ in. below floor surface. Comment (D.J.M.) : associated with microliths and other undated Australian prehistoric artifact types.

\section{Kenniff Cave series, Queensland}

Wood-charcoal lumps from Kenniff Cave, Mt. Moffatt Sta. $\left(24^{\circ} 51^{\prime} \mathrm{S}\right.$ Lat, $148^{\circ} 01^{\prime}$ E Long), Central Queensland. Coll. 1960 and subm. by D. J. Mulvaney.

\section{NPL-32. Kenniff Cave, 1}

Sample 1 from depth of $2 \mathrm{ft}$ in evenly stratified cave floor.

\section{NPL-33. Kenniff Cave, 2 \\ $12,900 \pm 170$ \\ 10,950 в.c.}

Sample 2 from depth of $6 \mathrm{ft} 3 \mathrm{in}$. from surface of cave floor. Comment (D.J.M.) : This site has since been re-excavated and from a depth of $5 \mathrm{ft}$ to the bottom of the deposit were found numerous implements whose only parallels are with Tasmanian types, not mainland. This sample is the first stratigraphic evidence that man was in Australia during the Pleistocene and moreover is underlain by over $3 \mathrm{ft}$ of human occupation layers.

Date list:

\section{REFERENCES}

USGS I Suess, 1954

Lamb, H. H., 1959, The changing climate: New Scientist, v. 6, p. 740-744.

Manley, G., 1945, Has the climate of N. W. Scotland deteriorated since 1700?: Royal Meteorological Soc. Quart. Jour., v. 71, p. 154-156.

McBurney, C. B. M., 1961, Absolute Age of Pleistocene and Holocene Deposits in the Haua Fteah: Nature, v. 192, no. 4803, p. 685-686.

1962, Absolute Chronology of the Paleolithic in Eastern Libya and the Problem of Upper Paleolithic Origins: Adv. of Sci., v. 18, no. 75, p. 494-497.

McBurney, C. B. M., Trevor, J. C. and Wells, L. H., 1953, The Haua Fteah Fossil Jaw: Royal Anthropol. Inst. Gt. Britain and Ireland Jour., v. 83, pt. 1, p. 71-76.

Suess, H. E., 1954, U. S. Geological Survey radiocarbon dates I: Science, v. 120, p. 467. 473. 